\title{
HOST-PARASITE RELATIONSHIP OF ERGASILUS LABRACIS KRØYER (CYCLOPIDEA, ERGASILIDAE) AND THE STRIPED BASS, MORONE SAXATILIS (WALBAUM) FROM THE LOWER CHESAPEAKE BAY (1)
}

\author{
I. PAPERNA* and D. E. ZWERNER**
}

\begin{abstract}
SUMMARY. Epithelial hyperplasia was the most distinctive pathological change in gill filaments of striped bass, Morone saxatilis (Walbaum), from the lower Chesapeake Bay infested by Ergasilus labracis Krøyer. This tissue reaction initiated in the filament area most adjacent to the mouth of the attached parasite. Interruption of parasite egg sac production and eventual dislodgement associated with swelling of the gill filaments occurred unilaterally on gill arches of either side of the branchial basket.

The largest number of parasites in all fish was found on the first outer hemibranch while abundance on successive hemibranchs decreased in rank order. Copepods on the inner hemibranch, however, were least numerous on the first inner hemibranch and more numerous on the fourth inner hemibranch. On the whole, the number of parasites attached to the outer hemibranch outnumbered the number of parasites established on the inner hemibranchs. This differential settlement was most evident in low to moderate infections and became less apparent in heavy infections. Newly settled copepods showed highest abundance on the third arch and least abundance on the first and fourth arches. The causes for this differential distribution on the gill arches are discussed.
\end{abstract}

\section{Relation hôte-parasite entre Ergasilus labracis Krøyer (Cyclopidea : Ergasilidae) et le "striped bass" Morone saxatilis (Walbaum) de la partie basse de la baie de Chesapeake}

RÉSUMÉ. Une hyperplasie épithéliale est l'effet pathologique le plus caractéristique observé dans les filaments branchiaux de $M$. saxatilis de la baie de Chesapeake, infesté par ce Cyclopidé. Cette réaction tissulaire commence dans l'aire filamenteuse la plus proche du parasite fixé. Une interruption de la ponte dans le sac ovigère et un éventuel délogement du parasite, associés à l'œdème des filaments branchiaux, se sont produits unilatéralement sur les arcs branchiaux de chaque côté de la poche branchiale.

Chez tous les poissons, le plus grand nombre de parasites a été trouvé sur la $1^{\text {re }}$ hémibranchie

* The Heintz Steinitz Marine Biology Laboratory, the Hebrew University of Jerusalem, Eilat, Israel.

** Virginia Institute of Marine Science, Gloucester Point, Va. 23062 U.S.A.

(I) Contribution No. $\mathrm{IOO}_{4}$ from the Virginia Institute of Marine Science, School of Marine Science, College of William and Mary. This research was accomplished while the senior author was an NSF Senior Foreign Scientist Fellow in the School of Marine Science of the College of William and Mary.

Accepté le 16 juin $198 \mathrm{I}$. 
externe, tandis que ce nombre diminuait progressivement sur les hémibranchies successives. Cependant, les Copépodes des hémibranchies internes étaient moins nombreux sur la $1^{\text {re }}$ hémibranchie interne et plus nombreux sur la $4^{\mathrm{e}}$ hémibranchie interne. Dans l'ensemble, le nombre de parasites fixés sur les hémibranchies externes dépassait celui des parasites logés dans les hémibranchies internes. Cette différence de localisation était plus évidente dans les infections faibles ou modérées, mais devenait moins apparente dans les infections fortes. Une nouvelle invasion de Copépodes montrait une abondance plus grande sur le $3^{\mathrm{e}}$ arc et moindre sur les $1^{\mathrm{er}}$ et $5^{\mathrm{e}}$ ares. Les causes de cette distribution différente sur les ares branchiaux sont discutées.

Prolific species of Ergasilidae such as Ergasilus sieboldi, E. lizae and Sinergasilus major have been shown to be pathogenic to their fish hosts by causing gill destruction, emaciation, and even death (Neuhaus, 1929; Schaperclaus, 1954; Abrosov and Bauer, 1959; Bauer and Babaev, 1964; Lahav and Sarig, 1967). Heavy infestations of Ergasilus labracis Krøyer were abundant on the gills of striped bass (Morone saxatilis) from the lower Chesapeake Bay water system (Paperna and Zwerner, 1976 , a, b) with individual gill arches of some hosts lodging as many as 100 or more parasitic copepods. The overall prevalence of E. labracis was found to be over $90 \%$ in all localities sampled and it was found to be as euryhaline as its host, i.e., found in habitats with salinities ranging from $0.1 \%$ to $32.0 \%$. E. labracis was present and reproductively active throughout the year, suffering only a temporary slowdown in egg production at the beginning of the winter (Paperna and Zwerner, 1976b). The pathological effect of the parasite on the host and its differential distribution on gill arches are presented.

\section{Methods}

Striped bass over one year old were collected from the York, Rappahannock, Potomac, and James Rivers, lower Chesapeake Bay and from the Atlantic Ocean at Chincoteague from May 1972 through May 1973. Caught fish were kept on ice (for 1-5 hours) until they were brought to the laboratory. Gills were then removed and placed in individual bottles of $10 \%$ formalin. Copepods on each gill arch were counted. Histological preparations were made from $10 \%$ formalin fixed material. Paraffin embedded tissues were cut at 7-10 $\mu \mathrm{m}$ and stained in Harris' hematoxylin and eosin. Statistical analysis of the data included one factor analysis of variance and t-test for dependent paired data (at 95\% confidence level). Numerically and statistically processed data are filed at the Virginia Institute of Marine Science.

Counts of copepods were taken separately for full-sized females and juveniles, which were equivalent to $\mathrm{GH}$ and $\mathrm{J}+\mathrm{GJ}+\mathrm{G}$ groups respectively of Paperna and Zwerner (1976a, b). Fish were grouped by size, i.e., those above $270 \mathrm{~mm}$ and those below $270 \mathrm{~mm}$ fork length, and by infestation levels, i.e., "low" (less than 100 parasites per fish) and (high) (over 100 parasites per fish) or subdivided into more discrete infestation level classes. 

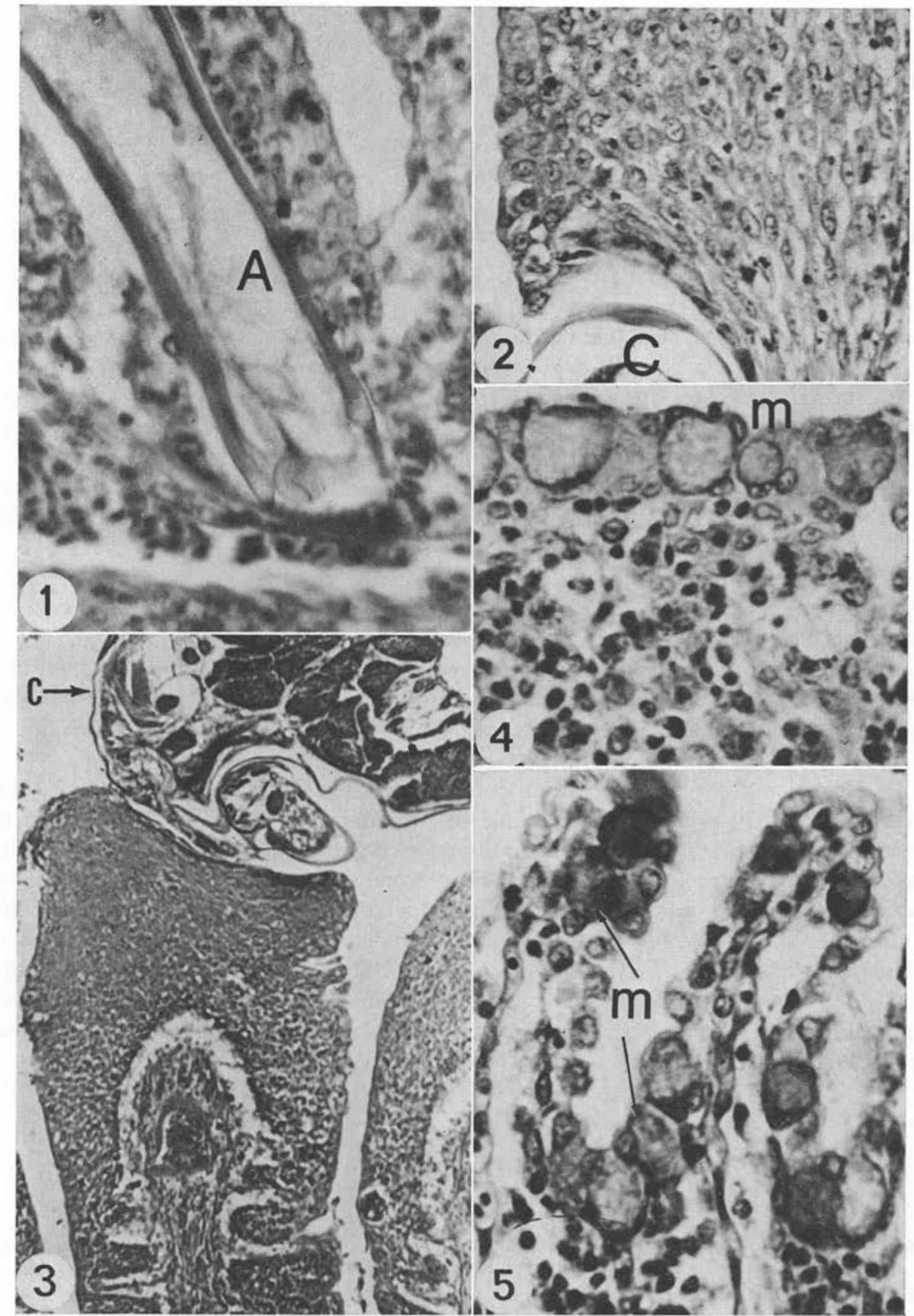

FIG. I à 5 .

Fig. I. - Attachment site of E. labracis on a gill filament showing the insertion of the second antenna (A) into the tissue. $(\% 600)$.

Fig. 2. - Epithelial hyperplasia of the gill filament adjacent to attachment site of ovigerous E. labracis $(\mathrm{C}) . \quad\left(x_{5} 10\right)$.

Fig. 3. - Extensive epithelial hyperplasia on filament area adjacent to the copepod head (C). $(x$ I 50$)$.

Fig. 4. - Epithelial hyperplasia of the filament, with mucus cell (m) proliferation and infiltration of lymphocytes and eosinophils. ( $\%$ 975).

Fig. 5. - Proliferation of mucus cells $(\mathrm{m})$ in gill lamellae. ( $\%$ ro20). 


\section{Results}

\section{1 - Gill tissue response to $\boldsymbol{E}$. labracis infections.}

No epithelial or granular tissue reaction was evident in the gill filament tissues around the inserted copepod antennae, although the tissue was pushed away or torn ( fig. 1); collagen surrounding the connective tissue core of the gill filaments was also torn at the points where the antennae were inserted. Tissue response to the parasite's presence took the form of epithelial hyperlpasia along the gill filament adjacent to the copepod's body (fig. 2,3) and was most prominent in the tissue in the nearest proximity to the parasite's mouth.

The initially localized hyperplasia at the attachment site progressively spread to the entire length of the gill filament, causing the major part or the entire gill filament to lose its lamellar structure.

Increased proliferation of mucus cells was observed along the margins of hyperplastic epithelial tissue (fig. 4) and sometimes also extended to unaffected gill lamellae (fig. 5).

Intensive infiltration by macrophages, lymphocytes and eosinophils over the entire gill filament was observed in some heavily infected gills (fig. 4, 5). Some sections through foci of hyperplastic epithelium revealed an increase in intercellular spaces filled with eosinophils.

Incidences of suppressed infestation on arches of one side of the branchial basket were observed in 8 fish, all caught during May and June when infection in fish is usually very high. Arches of one side of the branchial basket were considerably less infested than arches of the other side. None of the mature copepods on these arches carried egg sacs, while ovigerous copepods predominated on the heavily infested arches (Table I). The filaments of the gill arches where the infestation was depleted were pale and swollen (fig. 6, 7). Histological examination, however, failed to reveal any appreciable cellular changes in these filaments. Since these gills fixed post mortem, structural changes in the tissue which caused the gross pathological changes might have been obliterated before or during fixation.

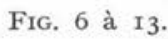

Fig. 6. - Unilaterally suppressed infection: Outer hemibranch, first arch, right branchial basket, heavily infested arch with focal hyperplasia. ( $\left.\chi_{\mathrm{I}} \cdot 3\right)$.

Fig. 7. - Unilaterally suppressed infection: Outer hemibranch, first arch, left branchial basket, same host fish as Fig. 6 , low infestation and pale swollen filaments. $(\%$ r.8).

Fig. 8-13. - Outer and inner hemibranchs of gill arches $\mathrm{I}$ thru 3 , from the right branchia 1 basket of a same fish ( $235 \mathrm{~mm}$ long), showing the attachment distribution of E. labracis ( $\%$ r. 8 ):

8. Outer hemibranch, arch $\mathrm{I}$.

ro. Outer hemibranch, arch 3.

9. Outer hemibranch, arch 2.

12. Inner hemibranch, arch 2 .

II. Inner hemibranch, arch I.

I3. Inner hemibranch, arch 3. 

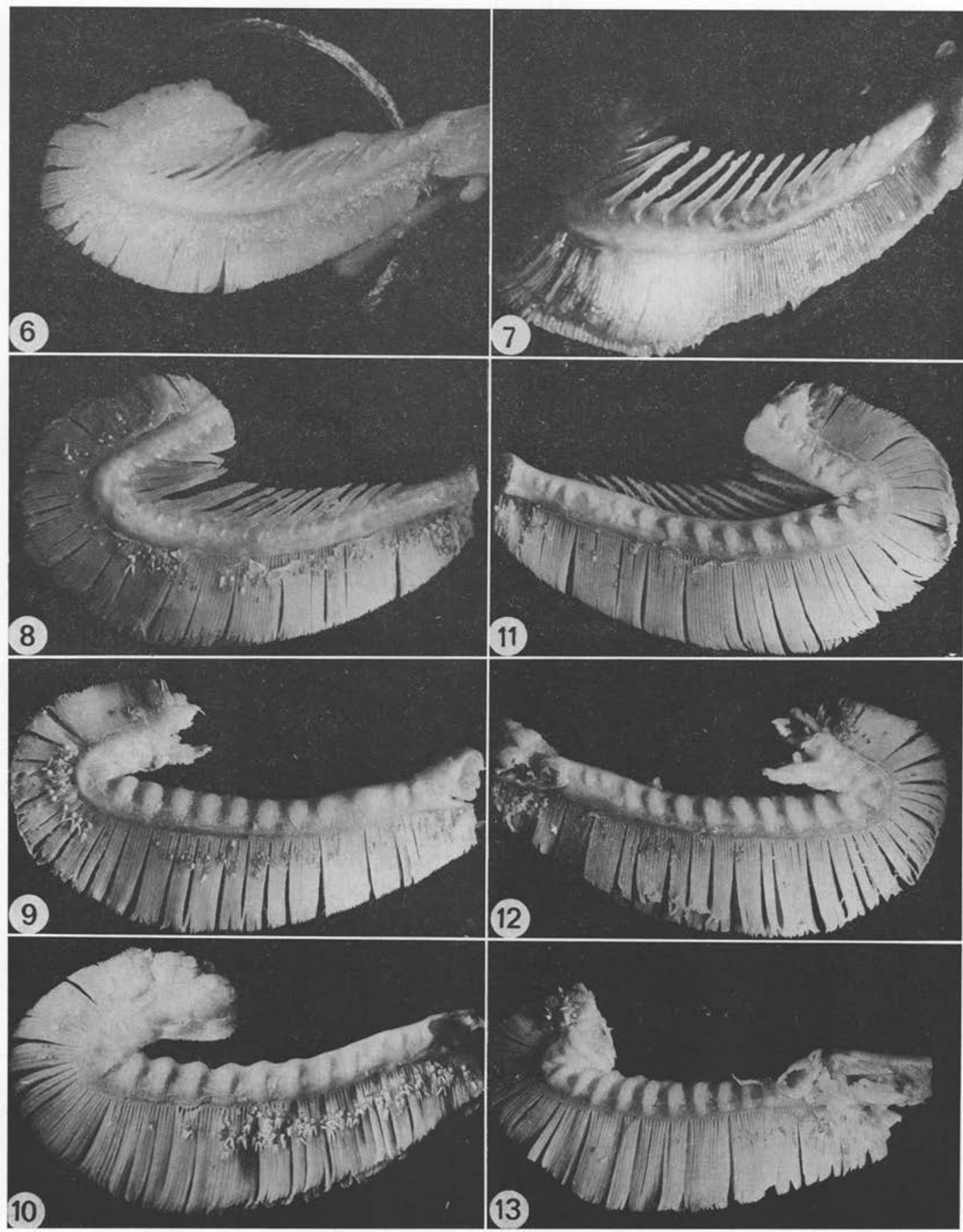

Fig. 6 à $\mathrm{I}_{3}$ 
TABLE I. - Unilaterally suppressed infestation by E. labracis in striped bass coupled with gross pathological changes in the filaments.

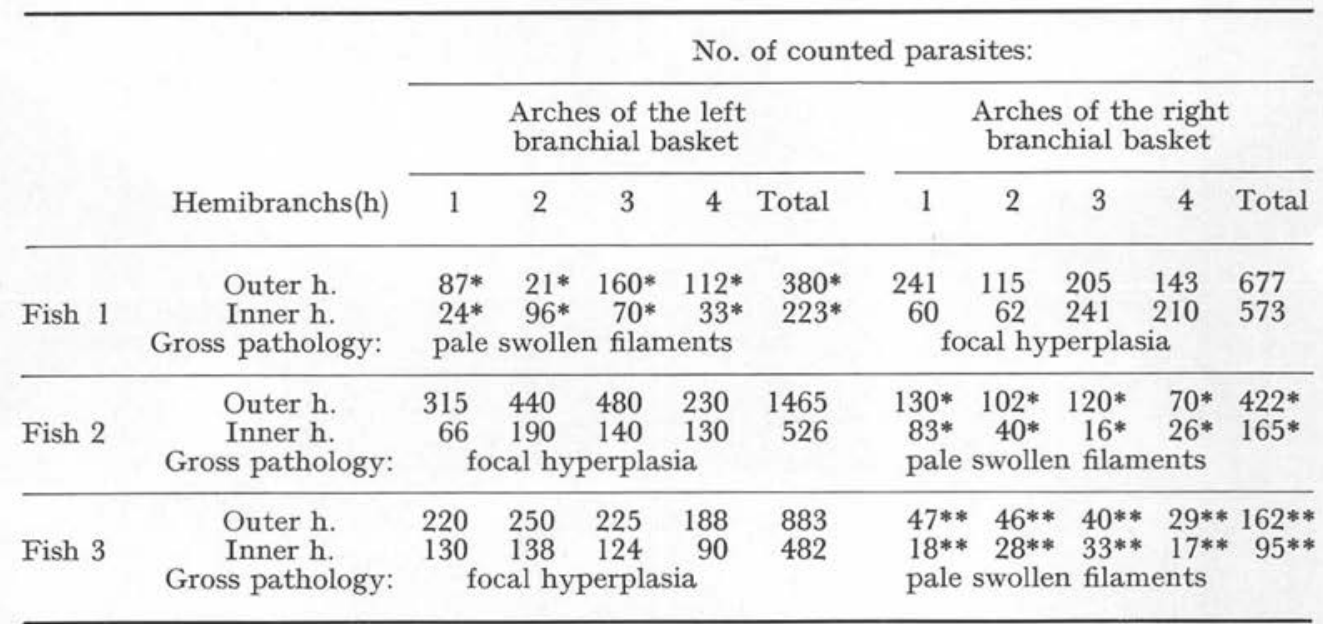

* Full size females without egg sacs;

** young females without egg sacs.

\section{2 - Mode of Copepod attachment and dispersal on gill arches.}

a - Attachment on the gill filament: In infections of less than 100 parasites per fish, individual copepods were found attached each to a separate gill filament, usually on the proximal second quarter of the filament. As density of parasites increased, several parasites often crowded together on the same gill filament, occasionally overlapping one another, but still limited to the same region along the gill filament (fig. 8-13). Newly attached juveniles and young premature females were apparently less selective in attachment site along the filament and were often found together on filaments already settled by a mature female or by other juvenile females.

b - Distribution on the gill arch: Parasites were attached exclusively to the external surface of each hemibranch of the gill arch. The highest number of attached copepods was at the ends of the arches near their articulation point. Parasites attached to the surface of the outer hemibranchs and the inner hemibranch of the fourth arch were also distributed throughout the length of the arch, with some preference to the ventral arm of the arch (fig. 8-10). Parasites on the inner hemibranch of arches 1-3 aggregated mainly on the ends of the arch of filaments (fig. 11-13) that extended beyond the margins of the gill aperture (fig. 14). As the infection became prolific, parasites were found, however, to extend their attachment also to the middle zone of the inner hemibranch. 
FIG. I4. - Relative sizes of gill arches from a $320 \mathrm{~mm}$ fish. Shaded areas indicate portions of the gill arches concealed beyond the margins of the gill aperture. ( $\left.\chi_{I}\right)$.

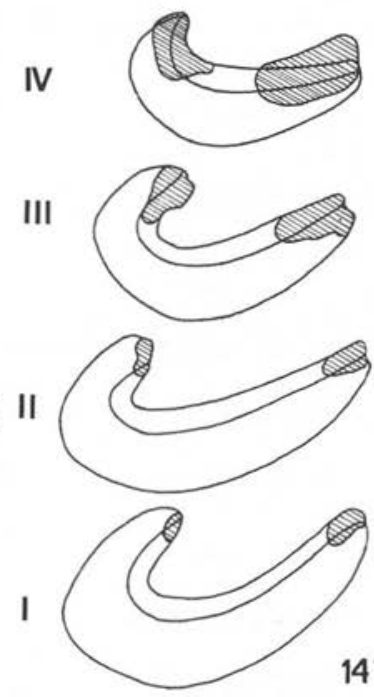

c - Differences in infestation levels between arches of the right and left branchial basket: No significant differences were generally (cases of unilaterally depleted infection excluded) observed in numbers of parasites attached to gills of left and right sides of the branchial basket (Table II). This was confirmed by t-test for dependent paired data for each individual fish.

TABLE II. - Abundance of E. labracis (mean number of copepods \pm SD) on arches of the left and right branchial basket (BB) in fishes grouped by different infestation level.

\begin{tabular}{crccc}
\hline Infestation load & $\mathrm{N}$ & Hemibranch: & Left BB & Right BB \\
\hline$>200$ p.p.f. & \multirow{2}{*}{18} & out & $179.60 \pm 82.05$ & $176.20 \pm 72.04$ \\
& & in & $52.80 \pm 46.50$ & $49.30 \pm 37.48$ \\
$100-199$ p.p.f. & \multirow{2}{*}{13} & out & $50.84 \pm 19.03$ & $57.92 \pm 33.40$ \\
& & in & $17.30 \pm 12.09$ & $10.63 \pm 8.05$ \\
40-99 p.p.f. & \multirow{2}{*}{8} & out & $25.50 \pm 8.92$ & $23.50 \pm 8.56$ \\
& & in & $4.00 \pm 2.39$ & $4.75 \pm 3.37$ \\
1-39 p.p.f. & \multirow{2}{*}{19} & out & $8.91 \pm 6.52$ & $7.91 \pm 4.44$ \\
& & in & $2.07 \pm 3.04$ & $0.81 \pm 0.87$ \\
\hline
\end{tabular}

$\mathrm{N}=$ No. of fish studied ;

p.p.f. $=$ parasites per fish.

\section{3 - Pattern of Copepod distribution between gill arches and hemibranchs.}

a - Mature Copepods (fig. 15): The number of mature, usually ovigerous, copepods attached to the outer hemibranchs significantly outnumbered (confirmed by t-test) the attached mature copepods on the inner hemibranchs. As infection level 


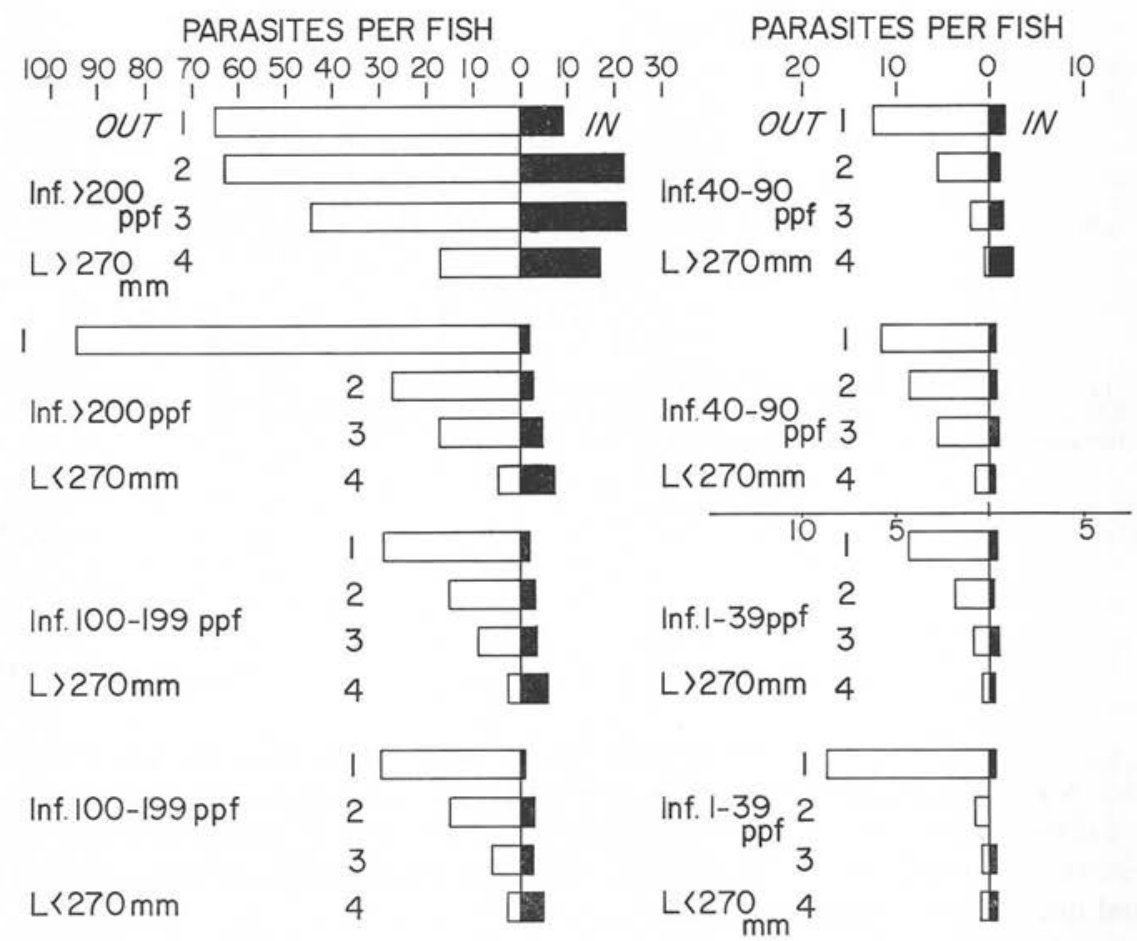

FIG. 15. - Differential distribution of mature E. labracis on the gills of striped bass grouped according to parasite load and length of hosts: (In - inner hemibranch; Inf. - intensity of infection range per individual fish; $\mathrm{L}$ - host's fork length; Out - outer hemibranch).

increased, the difference in numbers of attached parasites between the outer and inner hemibranch decreased, but the numbers of copepods on the outer hemibranch still predominated (Table III).

The number of mature copepods attached to the first outer hemibranch was significantly higher (by t-test) than on the successive hemibranchs; in the latter, abundance of attached copepods decreased in rank order. This differential distribution on the outer hemibranchs was also confirmed by analysis of variance (at $99 \%$ confidence level). However, in the heavily infected fish ( $>200$ parasites per fish), mainly in the larger size fish, the number of parasites found on the second outer hemibranch approached, or in few instances even exceeded their numbers on the first. Furthermore, in the few exceptionally heavily infected fish $(>1000$ parasites per fish) all gill arches on both sides were so overloaded that the distribution approached homogenicity. In the least infected fish, most copepods aggregated on the first outer hemibranch, their number on this arch was usually significantly higher than the overall number of copepods found in the successive hemibranchs.

The number of copepods on the inner hemibranch generally increased in reverse order i.e., they were least numerous on the first inner hemibranch and became more 
TABLE III. - Differential distribution of E. labracis between outer and inner hemibranchs of the gill arches.

\begin{tabular}{|c|c|c|c|c|c|c|c|c|}
\hline Groups: & I & II & III & IV & V & VI & VII & VIII \\
\hline Length (mm) & $>270$ & $<270$ & $>270$ & $<270$ & $>270$ & $<270$ & $>270$ & $<270$ \\
\hline Infestation (p.p.f.) & $>200$ & $>200$ & $100-199$ & $100-199$ & $40-99$ & $40-99$ & $1-39$ & $1-39$ \\
\hline $\begin{array}{l}\text { No. studied } \\
\text { No. Copepods: }\end{array}$ & 8 & 3 & 7 & 6 & 5 & 3 & 8 & 4 \\
\hline Outer hemibranchs & $\begin{array}{c}189 \\
\pm \quad 77\end{array}$ & $\begin{array}{l}142 \\
\pm 65\end{array}$ & $\begin{array}{c}54 \\
\pm 26\end{array}$ & $\begin{array}{c}54 \\
\pm \quad 29\end{array}$ & $22 \pm 8$ & $29 \pm 9$ & $\begin{array}{c}7.2 \\
\pm 5.7\end{array}$ & $\begin{array}{l}10.2 \\
\pm \quad 4.6\end{array}$ \\
\hline Inner hemibranchs & $\begin{array}{c}66 \\
\pm \quad 41\end{array}$ & $\begin{array}{r}17 \\
\pm \quad 9\end{array}$ & $\begin{array}{c}16 \\
\pm 13\end{array}$ & $\begin{array}{r}11 \\
\pm 9\end{array}$ & $6 \pm 3$ & $3 \pm 2$ & $\begin{array}{c}1.6 \\
\pm 2.5\end{array}$ & $\begin{aligned} & 1.1 \\
\pm & 2.0\end{aligned}$ \\
\hline
\end{tabular}

p p f. = parasites per fish.

numerous on the fourth inner hemibranch. As a result, the greatest discrepancy in parasite abundance occurred between first outer and inner hemibranchs while parasite abundance on the fourth inner hemibranch equaled or even exceeded the abundance of the fourth outer hemibranch.

The distribution pattern on the inner hemibranchs was less consistent than that observed on the outer hemibranchs and departed from this pattern particularly in the heaviest ( $>200$ p.p.f) and least ( $<100$ p.p.f) infected fishes.

Due to this inconsistency, differences could not be substantiated statistically by analysis of variance as well as by t-test for differences between indivudal arches, particularly between adjoining arches.

b - Juvenile female Copepods (fig. 16): The dispersal of juvenile copepods in fish with low infection followed the same pattern described above for infections consisting of mature copepods and was substantiated by analysis of variance and by t-test for differences between outer and inner hemibranches and between individual arches.

In fish with high infections, however, the pattern of distribution on the gill arches distinctly deviated from that of the mature copepods. The largest number of juvenile copepods was found on both outer and inner hemibranchs of arch 3 , and their number on arches 1 and 4 was significantly lower (confirmed by t-test). On the average, arch 2 was somewhat less infested than arch 3 but differences were usually statistically insignificant. Inner hemibranchs were relatively heavily infested but still significantly less than the outer hemibranchs. In both heavy and low infected fish mature copepods on gills infested by juvenile copepods were dispersed in the same pattern observed in infections consisting only of mature copepods. This pattern of distribution was also confirmed statistically (by t-test) except for differences between adjoining arches in heavily infected fish. There, differences were insignificant, and consequently analysis of variance was also unapplicable. 


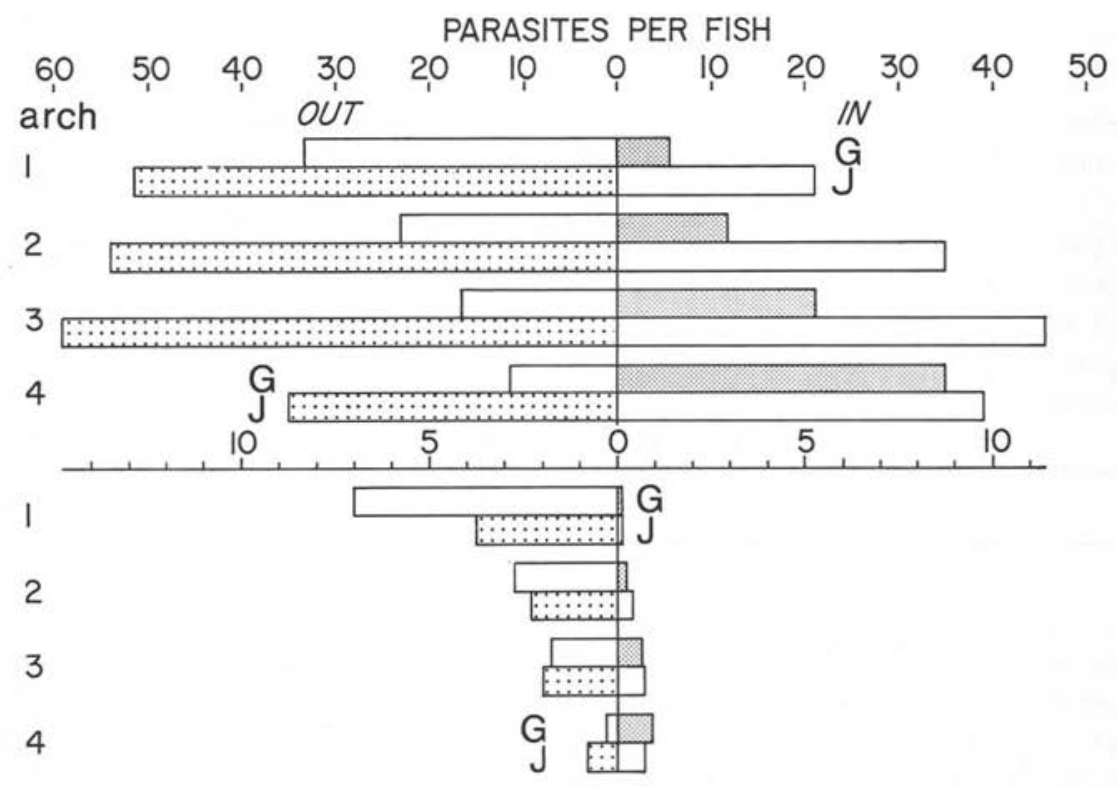

FIG. 16. - Differential distribution of juvenile (J) and mature $(G)$ E. labracis on gills of striped bass grouped according to high (top) and low (bottom) levels of infection. In - inner hemibranch, Out - outer hemibranch.

\section{Discussion}

Epithelial hyperplasia accompanied with an increase in number of mucus cells was the most distinct pathological change observed in gills infested by E. labracis. Such cellular response is apparently nonspecific (Schaperclaus 1954). It is characteristic of infections caused by ectoparasitic protozoa (Hines and Spira, 1974; Ellis and Wootten, 1978; Hoffman et al., 1979; Paperna, 1980), a number of monogeneans (Wilde, 1935; Litta, 1941; Paperna, 1964a; Putz and Hoffman, 1964; Molnar, 1972), parasitic copepods of the genus Ergasilus, Lamproglena, larval Lernaeoceridae (Kabata, 1958; Paperna and Thurston, 1968; Fryer, 1968; Kabata, 1970); and glochidia (Snieszko, 1969). No response was seen in the gill tissue surrounding the copepod's inserted antennae. Hyperplasia of the epithelium developed in the host tissue which came in closest contact with the body of the copepod, the mouth in particular rather than that directly perforated by the attachment organs. A similar phenomenon has been observed in gill infections with the monogenean Dactylogyrus vastator (Paperna, 1964a). Halisch (1939) suggested that digestion in Ergasilus is external and Kabata (1970) reported that a proteolytic secretion in Ergasilus dissolved gelatin in vitro. Such a secretion could be a source of irritation to gill tissue and the cause of hyperplasia. 
Of particular interest was the cessation of egg sac production and apparent increase in rate of detachment of copepods taking effect unilaterally on arches of one side of the branchial basket. Increase in mucus secretion and epithelial hyperplasia were reported to suppress infections by integumental parasites (Nigrelli, 1937 and Paperna, 1964a, b). The distinct gross pathological changes in the filaments which accompanied this suppression of infection of $E$. labracis could not be substantiated histologically, but possible structural or inflammatory changes were suggested. Its localized occurrence, however, precludes the possibility of a general systemic response.

Paling (1968) used glochidia for estimating relative volumes of water flowing over the gills of the brown trout, Salmo trutta. He determined that most of the ventilating current flows through the third gill slit, i.e., between the third and fourth gill arches, while very little flows through the first and fourth slits. Llewellyn (1956) suggested in his study on the mode of attachment of monogenean gill parasites that the greater number of larvae brought to those gills received the greater gill ventilating current. The final pattern of attachment along the gills, on the other hand, will be determined by the parasites' ability to maintain their attachment against the gill ventilating current.

Maximum abundance on the second and third arches suggests a preference for better ventilation and consequently, the need for better attachment ability. It was reported for Ergasilus siboldi (Abrosov and Bauer, 1959) as well as for several species of Monogenea (Llewellyn, 1956; Suydam, 1971).

Conversely, parasites confined to the first and fourth arches apparently exhibit a reduced ability to maintain their attachment on vigorously ventilated arches and, on the other hand, are apparently adapted to survive in poorly ventilated zones of the gills. The latter pattern is seen in the distribution of E. labracis ${ }^{1}$.

The distribution of mature $E$. labracis on the arches is consequently in an inverse relationship with the amount of ventilating current passing over the arches. Inner hemibranchs of arches 1-3 and outer hemibranch of arch 4, by being exposed to greater ventilating currents, apparently offer less favorable conditions for survival of this copepod. In these hemibranchs copepods restrict their attachment to the filaments at the end of the arch concealed behind the margin of the gill aperture. In extremely heavy infestations the differential distribution, however, along the hemibranchs of the gill arches becomes less distinct and may almost approach an even distribution. The parasites' loss due to ventilating current is apparently actively compensated for by a new infestation.

Surface area of the gill arch is also an important factor. The filaments are apparently limited in their capacity to carry attached copepods. Consequently,

I Preference to arch I and arches I and 4 by several monogeneans (Diplectanum spp. and Erpenstrema mugilis) were reported by Lambert and Maillard (I975) and Lambert and Sanfilippo (1977); however, here ventilating current was not likely to be the prime factor. 
although conditions for survival are equal in the outer hemibranch of the first arch and inner hemibranch of the fourth arch, the number of attached copepods is considerably higher on the first arch. This is also apparently the cause for more pronounced settlement of copepods on the second arch in extremely heavy infestation in larger fish than in smaller fish. Copepods on overcrowded filaments are apparently more vu nerable to detachment due to ventilating currents.

The preferential settlement of newly attached copepods on the median arches receiving the greater ventilating current is particularly evident in fish exposed to high infestation levels, and thus follows the pattern of settlement observed in glochidia and larvae of Monogenea (Llewellyn, 1956; Paling, 1968). This pattern was less evident in fish exposed to low infestation. The number of settling larvae in low or even moderate infections is apparently not sufficient to compensate for the loss of copepods from the median arches subjected to stronger ventilating currents.

Acknowledgments We thank Mr. C. E. Richards (decd.) and Dr. J. V. Merriner of the Ichthyology Department, Virginia Institute of Marine Science, who respectively furnished most of the striped bass over one year old and provided much helpful advice. We appreciate the photographic assistance of Mrs. Y. Paperna and histological services rendered by Mrs. P. B. Berry. The excellent technical assistance of Mrs. S. M. Jarvis is especially acknowledged.

\section{REFERENCES}

Abrosov V. N., Bauer O. N. : Ergasilosis of Coregonus peled in the lakes of the Pskov District [in Russian]. Izv. Gos. Nauch. issled. Inst. Ozer. Rech. Rybn. Khoz., 1959, 49, 213-216.

BAUER O. N., BABAEv B. : Sinergasilus major (Markewitsch, 1940), its biology and its pathological importance. [in Russian]. Izv. Akad. Nauk Turkm. SSR Ser. Biol. Nauk, I964, 3, 63-67.

Ellis A. E., Wootten R. : Costiasis of Atlantic salmon Salmo salar L. smolts in seawater. J. Fish. Dis., 1978, $1,389-393$.

FRYER G. : The parasitic Crustacea of African freshwater fishes; their biology and distribution. J. Zool. Lond., I968, is 6, 45-95.

Halisch W. : Anatomie und Biologie von Ergasilus minor Halisch. Z. Parasitenk., I939, II, 284-330.

HINEs R. S., SPIRA D. T. : Ichthyophthiriasis in the mirror carp Cyprinius carpio (L.). III. Pathology. J. Fish Biol., 1974, 6, 189-196.

Hoffman G., Kazubski S. L., Mrtchell A. J., Smrth C. E. : Chilodonella hexasticha (Kiernik, 1909) (Protozoa, Ciliata) from North American warmwater fish. J. Fish Dis., I979, 2, I $53-$ I 57 .

Kabata Z. : Lernaeocera obtusa n. sp.; its biology and its effects on the haddock. Mar. Res. Scot., $1958,3, \mathrm{I}-26$.

Kabata Z. : Diseases of fishes. Book I. Crustacea as enemies of fishes. T.F.H. Publications, Jersey City, N.J., r970.

LAHAV M., SARIG S. : Ergasilus sieboldi Nordmann infestation of grey mullet in Israel fish ponds. Bamidgeh, 1967, 19, 69-80.

Lambert A., Maillard C. : Répartition branchiale de deux Monogènes : Diplectanum aequans (Wagener, I857) Diesing, I858 et Diplectanum laubieri Lambert et. Maillard, I974 (Monogenea, Monopisthocotylea) parasites Simultane's de Dicentrarchus labrax (Téléostéen). Ann. Parasitol. Hum. Comp., 1975, so, 69r-699. 
Lambert A., SAnfilippo D. : Position systématique et biologie d'Ergenstrema mugilis Paperna, 1964 (Monogenea, Monopisthocotylea) parasite de Liza (Liza) ramada (Risso, I826) (Téléo-

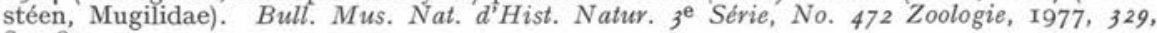
$823-831$.

Llewellyn J. : The host-specificity, micro-ecology, adhesive attitudes, and comparative morphology of some trematode gill parasites. J. Mar. Biol. Ass. U.K., I956, 35, II3-127.

Molnar K. : Studies on gill parasitosis of the grasscarp (Ctenopharyngodon idella) caused by Dactylogyrus lamellatus Achmerov, 1952. IV. Histopathological changes. Acta. Vet. Acad. Sci. Hung., 1972, 22, 9-24.

Neuhaus E. : Untersuchungen über die Lebensweise von Ergasilus sieboldi Nordmann. Z. Fisch. $1929,27,339-397$.

NigRelli R. F. : Further studies on the susceptibility and acquired immunity of marine fishes to Epibdella melleni, a monogenetic trematode. Zoologica, 1937, 22, 185-192.

PALING J. E. : A method of estimating the relative volumes of water flowing over the different gills of a freshwater fish. J. Exp. Biol., I968, 48, 533-544.

PAPERNA I. : Host reaction to infestation of carp with Dactylogyrus vastator Nybelin, I924 (Monogenea). Bamidgeh, 1964a, 16, I29-141.

PAPERna I. : Competitive exclusion of Dactylogyrus extensus by Dactylogyrus vastator (Trematoda, Monogenea) on the gills of reared carp. J. Parasitol., 1964b, 50, 94-98.

PAPERna I. : Amyloodinium ocellatum (Brown, I93I) (Dinoflagellida) infestations in cultured marine fish at Eilat, Red Sea: epizootiology and pathology. J. Fish Dis,. 1980, 3, 363-372.

PAPERna I., Thurston J. P. : Report on ectoparasitic infections of fresh water fish in Africa. Bull. Off. Int. Epizoot., 1968, 69, I197-1206.

Paperna I., Zwerner D. E. : Parasites and diseases of striped bass, Morone saxatilis (Walbaum), from the lower Chesapeake Bay. J. Fish. Biol., I976a, 9, 267-281.

Paperna I., Zwerner D. E. : Studies on Ergasilus labracis Krøyer (Cyclopidea, Ergasilidae) parasitic on striped bass, Morone saxatilis, from the lower Chesapeake Bay. Part I: Distribution, life cycle, and seasonal abundance. Can. J. Zool., I976b, 54, 449-462.

Putz R. E., Hoffman G. L. : Studies on Dactylogyrus corporalis n. sp. (Trematoda: Monogenea) from the fallfish Semotilus corporalis. Proc. Helminthol. Soc. Wash., I964, 31, I39-I43.

Schaperclaus W. : Fischkrankheiten. Akademie Verlag, Berlin, 1954.

SNIEszko S. F. : Cold-blooded vertebrate immunity to metazoa. In: G. J. Jackson, R. Herman and I. Singer, eds. Immunity to parasitic animals Vol. I, pp. 267-275, Appleton-CenturyCrofts, N.Y., 1969.

SuYdAm E. L. : The micro-ecology of three species of monogenetic trematodes from the BeaufortCape Hatteras area. Proc. Helminthol. Soc. Wash., I971, 38, 240-246.

WILDE J. : Der Schleiendactylogyrus (Dactylogyrus macracanthus) und die Schädigung der Schleinenkierne durch diesen Parasiten. Fisch. Ztg., I935, 38, 66I-663. 